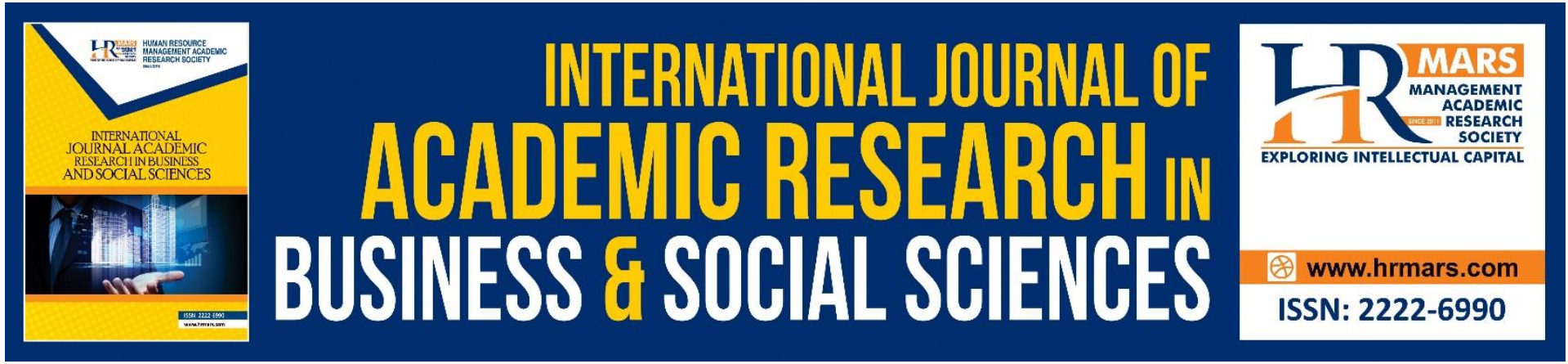

\title{
Language Learning Strategies Employed by Successful Language Learners
}

Amira Dayana Hanafiah, Farzaana Abdul Kadir, Siti Munirah Kamaruddin, Siti Nur Laily Hussin \& Harwati Hashim

To Link this Article: http://dx.doi.org/10.6007/IJARBSS/v11-i6/10095

DOI:10.6007/IJARBSS/v11-i6/10095

Received: 19 April 2021, Revised: 21 May 2021, Accepted: 05 June 2021

Published Online: 19 June 2021

In-Text Citation: (Hanafiah et al., 2021)

To Cite this Article: Hanafiah, A. D., Kadir, F. A., Kamaruddin, S. M., Hussin, S. N. L., \& Hashim, H. (2021). Language Learning Strategies Employed by Successful Language Learners. International Journal of Academic Research in Business and Social Sciences, 11(6), 1363-1378.

Copyright: (c) 2021 The Author(s)

Published by Human Resource Management Academic Research Society (www.hrmars.com)

This article is published under the Creative Commons Attribution (CC BY 4.0) license. Anyone may reproduce, distribute, translate and create derivative works of this article (for both commercial and non-commercial purposes), subject to full attribution to the original publication and authors. The full terms of this license may be seen

at: http://creativecommons.org/licences/by/4.0/legalcode

Vol. 11, No. 6, 2021, Pg. 1363 - 1378

http://hrmars.com/index.php/pages/detail/IJARBSS

JOURNAL HOMEPAGE

Full Terms \& Conditions of access and use can be found at http://hrmars.com/index.php/pages/detail/publication-ethics 


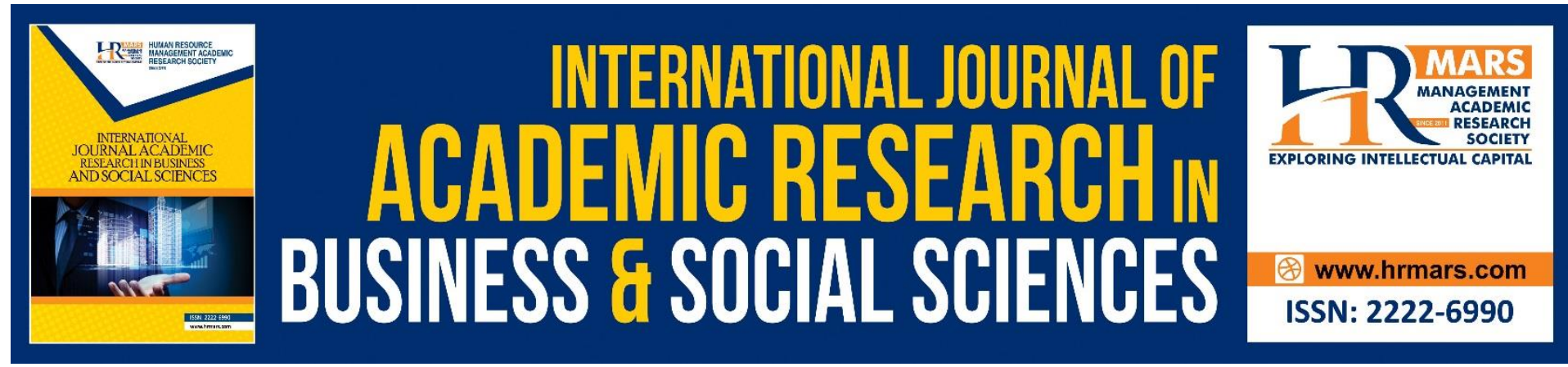

\title{
Language Learning Strategies Employed by Successful Language Learners
}

\author{
Amira Dayana Hanafiah, Farzaana Abdul Kadir, Siti Munirah \\ Kamaruddin, Siti Nur Laily Hussin, \& Harwati Hashim \\ Faculty of Education, Universiti Kebangsaan Malaysia
}

\begin{abstract}
Language Learning Strategies (LLSs) act as a catalyse to increase learners' understanding of the target language. Learners need to explore a wide range of LLSs and decide which strategy works best for them because there is no single strategy that has been proven to be the universal success of learning a second language. This paper aims to identify the language learning strategies preferred by successful language learners. The study employed a quantitative research design which involved 54 successful language learners who are serving as teachers and lecturers of English as a second language (ESL) at various learning institutions in Malaysia An online survey with a Likert Scale of 1 to 5 adopted from the Strategy Inventory for Language Learning (SILL) by Oxford (1990) was used to identify the language learning strategies preferred by the respondents and results revealed that metacognitive, compensation, social, memory and cognitive strategies were the most frequently employed while affective strategies were moderately employed strategies among the participants. Therefore, it is revealed that the successful language learners are highly aware of their language learning strategies used and this may not only benefit them as a successful language learner but also their students as they may train their students using varied strategies to succeed in English language learning.

Keywords: Language Learning Strategies (LLSs), Strategy Inventory for Language Learning (SILL), Successful Language Learners, English as Second Language (ESL)
\end{abstract}

\section{Introduction}

English is a language that has been recognized as a global language that widely been used around the world. Learning English is pivotal as in this modernization and advancement of technology, English language is not only important for academic purposes, but also for communication, information, and technology. Thus, it is undeniable that having a second language is crucial for students to enhance their competency and knowledge as an individual. Language learning strategies (LLS) is a part of the language field which is developed to identify the suitable learning strategies that can be utilised for the language learner. In addition, according to Oxford (1990), learners will be able to improve their perception, proficiency, selfconfidence, storage, reception, retention and retrieval of the language learned through using the appropriate strategies. Therefore, by identifying and implementing the ideal language 
learning strategies (LLS), the learners along with the educators will intensify their language competency.

In the context of Malaysia, LLS is crucial as the English language is considered a vital need especially in our education system. This is due to the fact that English is used as our second language, and we are one of the countries in Asia which implement a bilingual education system (Darmi \& Albion, 2013). In addition, Yunus et al (2013) mentioned that it is significant to understand what students do in their language learning process and how it affects language success in the method that supports students in the learning of the English language. Due to that, it is necessary for the educators and learners to choose the suitable and right strategies to be implemented in their learning process. Nevertheless, it cannot be denied that very limited studies of language learning strategies (LLS) have been conducted, especially for successful language learners who are in-service ESL educators (Koç, 2017). This research is significant for the stakeholder to design and provide a better strategy to be implemented in our education system in the future.

\section{Research Objective}

- To identify the language learning strategies preferred by successful language learners.

\section{Literature Review \\ Definition and Classification of LLS}

The understanding of language learning strategies (LLS) is becoming more significant with the increasing importance of language learning around the world. This is because LLS aid the development of language learning among learners. Many scholars have given their definitions of LLS based on how the learners utilize the strategies to acquire and enhance their language skills. Some strategies are regarded as effective, yet some others are less effective.

Wenden \& Rubin (1987) defined learning strategies as "any sets of operations, steps, plans, routines used by the learner to facilitate the obtaining, storage, retrieval and use of information" (p. 19). Oxford (1990) stated that LLS aims to make the language learning process "easier, faster, more enjoyable, more self-directed, more effective and more transferrable to new situations" (p. 8). O'Malley and Chamot (1990) termed LLS as "special thoughts or behaviors that individuals use to help them comprehend, learn or retain new information" (p. 1). Cohen (1998) referred LLS as conscious actions and efforts taken and identified by the learners in the language learning process. LLS can be defined as a set of techniques used consciously in language learning to increase learners' autonomy and improve learners' language skills.

According to Adan \& Hashim (2021), there are many researchers who are constantly contributing to the study of LLS by improving the classification and typology of LLS since 1970s. The most common and comprehensive classification of LLS was introduced by Oxford. Oxford (1990) had classified LLS into two categories which are direct strategies and indirect strategies. Direct strategies encompass direct learning and mental processing of the language such as compensation, memory and cognitive strategies. Compensation strategies enable speakers to overcome their knowledge gaps and sustain the conversation, while memory strategies are used to store information, and cognitive strategies refer to the mental strategies that learners use to make sense of their learning (Oxford, 1990). Indirect strategies consist of metacognitive, affective and social strategies. These strategies support the language learning indirectly. Metacognitive strategies help learners to be self-regulated, affective strategies are concerned with learners' motivation, attitudes and emotional 
requirements, social strategies increase learners' social interaction in the target language (Oxford, 1990).

Table 1: Classification of Language Learning Strategies (Oxford, 1990)

\begin{tabular}{|c|c|c|c|}
\hline Direct Strategies & & Indirect Strategies & \\
\hline \multirow{4}{*}{ Memory strategies } & $\begin{array}{l}\text { Create mental } \\
\text { linkage }\end{array}$ & \multirow{4}{*}{$\begin{array}{l}\text { Metacognitive } \\
\text { strategies }\end{array}$} & Learning centering \\
\hline & $\begin{array}{l}\text { Apply image and } \\
\text { sounds }\end{array}$ & & Learning planning \\
\hline & Review & & $\begin{array}{l}\text { Self-evaluating in } \\
\text { learning }\end{array}$ \\
\hline & Employ action & & $\begin{array}{l}\text { Self-monitoring for } \\
\text { errors in the learning }\end{array}$ \\
\hline \multirow{5}{*}{ Cognitive strategies } & Reasoning & \multirow{5}{*}{ Affective strategies } & Anxiety reduction \\
\hline & Practice & & Self-rewards \\
\hline & $\begin{array}{l}\text { Receive and send } \\
\text { messages }\end{array}$ & & \\
\hline & Analyze & & seli-encouragement \\
\hline & Summarize & & \\
\hline \multirow{3}{*}{$\begin{array}{l}\text { Compensation } \\
\text { strategies }\end{array}$} & Intelligent guess & \multirow{3}{*}{ Social strategies } & Asking questions \\
\hline & Overcoming & & Peer cooperation \\
\hline & $\begin{array}{l}\text { limitations in } \\
\text { speaking and writing }\end{array}$ & & $\begin{array}{l}\text { Improve cultural } \\
\text { competencies }\end{array}$ \\
\hline
\end{tabular}

\section{Factors Affecting Language Learning Strategies Used}

Previous literature has demonstrated that factors such as motivation, gender, age, learning styles, language proficiency and attitude influence the use of language learning strategies. However, the most common factor that affects LLS used highlighted by researchers is motivation. Adan \& Hashim (2021) stated that when learners are motivated to learn the language, they will increase their efforts to attain language proficiency. Shi (2017) stated that motivated learners usually employ more strategies than less motivated learners and their choices of strategies are heavily influenced by their purpose of learning the language. It is essential for teachers to educate learners on the strategies to learn the language and guide them on how to seek the best strategies that suit their learning styles and preferences to increase their chances of being successful language learners.

\section{Successful Language Learners}

The idea of good language learners began in the 1970's (Rubin, 1975) before becoming a topic of interest and discussion in Second Language Acquisition (SLA) over the next decade (O'malley and Chamot, 1990; Oxford \& Crookall, 1989). The previous studies describe good language learners as active language learners who are problem solvers for their own learning. This description is parallel to Nazri et al. (2016) who state that successful language learners demonstrate the urge to exploit an active mind, solve problems with positivity, devote sufficient time to accomplish different tasks and learn the necessary information through numerous resources. In short, they are very successful in acquiring the second language (L2) 
until they can proficiently use the language and fluently communicate in English (Hashim et al., 2018).

Rubin (1975) further characterised successful language learners as people who always monitor both their own utterances and others', try their best to deliver and receive the intended message and make use of opportunities to use the target language. They also use the input of the target language and make errors work, make the most of social means and language patterns. In addition, successful language learners also read extensively, strategise their language learning, and above all, they try out diverse learning strategies. These characteristics are similar to language strategies enlisted in Rubin's (1994); Embi's (2000) research which were deployed by successful language learners.

Unlike first language learning which is primarily possible through inherent reasons of developmental and experiential, second language acquisition is believed to be predominantly influenced by learning strategies (Fillmore and Swain 1984; O'Malley et al., 1985). Consequently, unfolding strategies utilised by successful second language learners has become the central focus of learning strategy research in the SLA literature. These studies fundamentally provide us with an understanding of what successful language learners do to acquire L2, so that, these strategies can be trained on less successful learners. According to O'Malley et al (1985), studies focusing on the impacts of strategy training on different kinds of tasks and learners indicate that strategy teaching significantly increases the students' performance on various problem-solving and reading tasks (e.g. Ernomo, 2018; Wittrock, Marks and Doctorow, 1975; O'Malley et al., 1985).

In the early studies Rubin (1975), it was determined that successful language learners constantly used certain forms of learning strategies, such as contextual guessing. After a while, it turned out that successful language learners did not always use the same set of strategies, but rather carefully orchestrated strategies that were relevant and systematic for specific L2 tasks. Conversely, it was found that less successful learners had a different manner of using the strategies in completing the tasks, which was described as arbitrary, unrelated, and uncontrolled (e.g. Abraham \& Vann, 1987; Chamot et al., 1996 as cited in O'Malley et al., 1985; Kiu \& Yamat, 2020). In Kiu \& Yamat's (2020) study of ESL primary students in Malaysia, it was revealed that the good learners used more strategies for active involvement and more frequently than did their weak learner counterparts, which was similar to Zakaria et al. (2018) research findings among secondary school students in Malaysia too. Likewise, many studies showed that successful language learners consistently used a greater variation of language learning strategies (e.g. Ang et al., 2017; Nazri et al., 2016; Rubaai \& Hashim, 2019; Zakaria et al., 2018).

Rubin (1975) examined what we can learn about good learners and how the strategies they use can assist us in learning a foreign language. It is proposed that by following good learning strategies, teachers can help less successful learners who typically have limited strategies to improve their language learning. Students who are attentive of the strategies and characteristics of successful language learners will more likely become efficient in their learning (Ang et al., 2017; Kiu \& Yamat, 2020; Lim et al., 2021; Nazri et al., 2016; Rahman, 2020; Rubaai \& Hashim, 2019; Rubin, 1975; Sarafianou \& Gavriilidou, 2015). Thus, teachers should take this opportunity to train their students to deploy the good learning strategies that are suitable for their students' needs (Ang et al., 2017; Basri \& Hashim, 2019; O'Malley et al., 1985; Rubaai \& Hashim, 2019; Rubin, 1975). In addition, it has been proven time and again that better performance or mastery of target language acquisition is caused by the use of 
language learning strategies (Ang et al., 2017; Hashim et al., 2018; Kiu \& Yamat, 2020; Nadif \& Benattabou, 2021; Rubin, 1975; Zare, 2012).

\section{ESL In Malaysia}

The Malaysia Education Blueprint 2013 - 2025 aims to be able to produce human capital for our country, who can be global players through one of the eleven shifts that ensures proficiency in English (MOE, 2013). This step is also mandated to address the problem of our education system that even after 11 years of formal instruction in schools does not produce reasonable English users (Naginder, 2006; Jalaludin et al., 2008 as cited in Musa et al., 2012). In addition to the ministry's efforts to rectify this issue, a curriculum based on Common European Framework of Reference (CEFR) is being implemented (MOE, 2015). According to the English Language Education Reform in Malaysia: The Roadmap 2015 - 2025, language learning strategies are vital in the context of CEFR (MOE, 2015). In order for students to attain language input or proficiency in the language, they need to perform tasks that require them to deploy language strategies.

Teachers are not being trained to familiarise their students with LLS even though learning strategies have been integrated into the language learning curriculum (Sarafianou \& Gavriilidou, 2015). Kussin et al (2018) acknowledged that our pedagogy practice is shifting to improve learners' language proficiency, along with myriad efforts and action plans to achieve the same goal. However, they critiqued that LLS has never received attention in teacher training, despite the fact that in almost every master plan, the word strategy was mentioned. Koç, (2017) highlighted that teachers cannot enhance their students' LLS use since they are not trained to do so. Perhaps this is the reason why Malaysia has fallen four places in 2019 Education First (EF) English Proficiency Index, as compared to 2018 and this trend followed in 2020 when we were placed at $30^{\text {th }}(E F, 2020$, p.7) as opposed to at 26th in 2019 (EF, 2019, p.6). Thus, it is hoped by investigating the LLS preferred by ESL educators in Malaysia will remind everyone of how explicitly training our students with good LLS helps them in acquiring English better (Kussin et al., 2018), just like how the ESL educators have successfully mastered the language through LLS.

\section{Methodology}

In this current study, a quantitative approach was used to examine the use of LLS among ESL educators in Malaysia.

\section{Research Design}

In order to recognise patterns among our samples either in their opinions, attitudes, behaviours or features (Creswell, 2012), a survey design was chosen as the research design of this current study. The Strategy Inventory for Language Learning (also known as SILL) by Oxford (1990) was adopted to be used as the online survey questionnaire.

\section{Instrumentation}

The online version of SILL was made available as the tool to for this study data collection. The questionnaire was divided into two parts, namely the demographic of the respondents and SILL. This inventory is made up of fifty items and uses a five-point Likert scale that ranges from 1 , which means they are very unlikely to use the mentioned strategy, to 5 , which indicates the likelihood that they will use the said strategy. The respondents evaluated themselves using this instrument and reflected on the extent to which they use various 
language strategies throughout their ESL learning journey. There are six categories tested namely, cognitive, memory, compensation, metacognitive, social, and affective strategies.

\section{Respondents}

The respondents of this study were 54 successful language learners who are ESL educators teaching in Malaysia. They are teaching in different educational institutions nationwide but all of them are successful language learners as they can only be parts of the system if they possess good command of the English language.

\section{Sampling Technique}

To ensure the sample possessed the characteristics of successful language learners, purposive sampling was used. A link to the online SILL survey was shared to a few online groups of ESL educators in Malaysia.

\section{Data Analysis}

Before using descriptive statistical analysis to analyse the data, the percentages and frequency of the responses were obtained from the instrument administered.

\section{Findings \& Discussion}

This section presents the results of this study and discusses the findings in relation to the literature. Tables are used to summarise the findings and further discussed according to the six language learning strategy domains tested in the questionnaire.

Table 2: Overall Mean Score of Language Learning Strategies

\begin{tabular}{lll}
\hline Language Learning Strategies & Mean & Rank \\
\hline Metacognitive & 4.2243 & 1 \\
\hline Compensation & 3.9599 & 2 \\
\hline Cognitive & 3.9563 & 3 \\
\hline Social & 3.8858 & 4 \\
\hline Memory & 3.5226 & 5 \\
\hline Affective & 3.2963 & 6 \\
\hline
\end{tabular}

Table 2 above presents the language learning strategies used by the participants based on the categories with the mean score of each category from the mostly used and least used. Oxford (1990) categorized the strategies in three range of scales from high (3.5 to 5), average (2.5 to 3.4) and low (1.0 to 2.4) in terms of the mean. Table 2 shows the mean score of each language learning strategies by category. Based on table 2, almost all of the language learning strategies are in the very frequently used by the respondents as their mean scores lie between 3.5 to 5 . By ranking, metacognitive strategies topped the rank followed by compensation strategies at the second place, cognitive strategies at third, social strategies at the fourth place and memory strategies at the fifth place. All the strategies' mean score is more between 3.5 to 5 which means they are highly used among the respondents. In addition, affective strategies are placed at the sixth place with the mean score of 3.2963 meaning they are averagely used among the respondents.

Nazri et al (2016) in their research among ESL learners in a university revealed exact same findings as in this research which the metacognitive strategies ranked the first followed by compensation, cognitive, social, memory and lastly affective. Similarly, Yunus et al. (2013) and Rahman (2020) in their research towards Malaysian gifted students and EFL learners 
respectively found that metacognitive strategies were used the most meanwhile the least rank was affective strategies. In addition, Ang et al. (2017), Ahamad (2019) as well as Adan and Hashim (2021) also found the corresponding result in their research where metacognitive strategies were the highest use among ESL learners. Koç (2017) in his study towards English teachers found that the teachers used least affective strategies because they believe that it is not necessary for them to decrease their anxiety since they can acquire the language by utilising more mechanical tasks such as repetitive writing and memorization can be acquired with the help of the dictionary or exercise with assessment. Thus, the metacognitive strategies are used by most of the language learners beyond their limitations including English educators.

The following tables (Table 3 to Table 8) display the percentage, frequency and mean of the responses for each item by the scale namely, "Never or almost never true of me" $(\mathrm{N})$, "Usually not true of me" (NT), "Somewhat true of me" (ST), "Usually true of me" (T) and "Always or almost always true of me" (AT). Each table represents one classification of language learning strategies based on SILL by Oxford (1990).

Table 3: Memory Strategy

\begin{tabular}{|c|c|c|c|c|c|c|c|}
\hline No & Item & $\begin{array}{l}N, n, \\
(\%)\end{array}$ & $\begin{array}{l}N T, n, \\
(\%)\end{array}$ & $\begin{array}{l}\text { ST, n, } \\
(\%)\end{array}$ & $\begin{array}{l}T, n, \\
(\%)\end{array}$ & $\begin{array}{l}\text { AT, n, } \\
(\%)\end{array}$ & Mean \\
\hline 1 & $\begin{array}{l}\text { I think of relationships } \\
\text { between what I already } \\
\text { know and new things I } \\
\text { learn in the English. }\end{array}$ & $\begin{array}{l}1 \\
(1.9)\end{array}$ & $\begin{array}{l}1 \\
(1.9)\end{array}$ & $\begin{array}{l}6 \\
(11.1)\end{array}$ & $\begin{array}{l}30 \\
(55.6)\end{array}$ & $\begin{array}{l}16 \\
(29.6)\end{array}$ & $\begin{array}{l}4.092 \\
6\end{array}$ \\
\hline 2 & $\begin{array}{l}\text { I use new English words } \\
\text { in a sentence so I can } \\
\text { remember them. }\end{array}$ & 0 & $\begin{array}{l}3 \\
(5.6)\end{array}$ & $\begin{array}{l}9 \\
(16.7)\end{array}$ & $\begin{array}{l}25 \\
(46.3)\end{array}$ & $\begin{array}{l}17 \\
(31.5)\end{array}$ & $\begin{array}{l}4.037 \\
0\end{array}$ \\
\hline 3 & $\begin{array}{l}\text { I connect the sound of a } \\
\text { new English word and } \\
\text { an image or picture of } \\
\text { the word to help me } \\
\text { remember the word. }\end{array}$ & $\begin{array}{l}3 \\
(5.6)\end{array}$ & $\begin{array}{l}3 \\
(5.6)\end{array}$ & $\begin{array}{l}10 \\
(18.5)\end{array}$ & $\begin{array}{l}23 \\
(42.6)\end{array}$ & $\begin{array}{l}15 \\
(27.8)\end{array}$ & $\begin{array}{l}3.814 \\
8\end{array}$ \\
\hline 4 & $\begin{array}{l}\text { I remember a new } \\
\text { English word by making } \\
\text { a mental picture of a } \\
\text { situation in which the } \\
\text { word might be used. }\end{array}$ & 0 & $\begin{array}{l}3 \\
(5.6)\end{array}$ & $\begin{array}{l}8 \\
(14.8)\end{array}$ & $\begin{array}{l}22 \\
(40.7)\end{array}$ & $\begin{array}{l}21 \\
(38.9)\end{array}$ & $\begin{array}{l}4.129 \\
6\end{array}$ \\
\hline 5 & $\begin{array}{l}\text { I use rhymes to } \\
\text { remember new English } \\
\text { words. }\end{array}$ & $\begin{array}{l}9 \\
(16.7)\end{array}$ & $\begin{array}{l}9 \\
(16.7)\end{array}$ & $\begin{array}{l}17 \\
(31.5)\end{array}$ & $\begin{array}{l}11 \\
(20.4)\end{array}$ & $\begin{array}{l}8 \\
(14.8)\end{array}$ & $\begin{array}{l}3.000 \\
0\end{array}$ \\
\hline 6 & $\begin{array}{l}\text { I use flashcards to } \\
\text { remember new English } \\
\text { words. }\end{array}$ & $\begin{array}{l}12 \\
(22.2)\end{array}$ & $\begin{array}{l}21 \\
(38.9)\end{array}$ & $\begin{array}{l}13 \\
(24.1)\end{array}$ & $\begin{array}{l}6 \\
(11.1)\end{array}$ & $\begin{array}{l}2 \\
(3.7)\end{array}$ & $\begin{array}{l}2.351 \\
9\end{array}$ \\
\hline 7 & $\begin{array}{l}\text { I physically act out new } \\
\text { English words. }\end{array}$ & $\begin{array}{l}7 \\
(13.0) \\
\end{array}$ & $\begin{array}{l}14 \\
(25.9) \\
\end{array}$ & $\begin{array}{l}13 \\
(24.1) \\
\end{array}$ & $\begin{array}{l}14 \\
(25.9) \\
\end{array}$ & $\begin{array}{l}6 \\
(11.1) \\
\end{array}$ & $\begin{array}{l}2.963 \\
0 \\
\end{array}$ \\
\hline 8 & $\begin{array}{l}\text { I review English lessons } \\
\text { often. }\end{array}$ & 0 & $\begin{array}{l}2 \\
(3.7)\end{array}$ & $12(22.2)$ & $\begin{array}{l}20 \\
(37.0)\end{array}$ & $\begin{array}{l}20 \\
(37.0)\end{array}$ & $\begin{array}{l}4.074 \\
1\end{array}$ \\
\hline
\end{tabular}




\begin{tabular}{lllllll}
\hline 9 I remember new English & $2(3.7)$ & 12 & $16(29.6)$ & 19 & $5(9.3)$ & 3.240 \\
words or phrases by & & $(22.2)$ & & $(35.2)$ & & 7 \\
remembering their & & & & & \\
location on the page, on & & & & \\
the board, or on a street & & & & \\
sign.
\end{tabular}

Table 3 shows the memory strategies where the strategy "I remember a new English word by making a mental picture of a situation in which the word might be used" (item 4) was the mostly used among the other memory strategies with the mean of 4.1296. The finding was in line with the research done by Lim et al. (2021). The least used memory strategy "I used flashcards to remember new English words" (item 6), holding the mean 2.3519. The findings are parallel with Yunus et al. (2013), Nazri et al. (2016), Ang et al. (2017) and Rahman (2020). According to Oxford (2003) memory strategies support learners by enabling them to link concept in second language without necessarily having deep understanding which also often positively associated with second language proficiency. However, when learners' vocabulary and structure of the target language enlarge, they tend to use lesser memory strategies. It is believed that, learning language using flashcards is normally related to very young learners while adult learners utilised other memory strategies (Lim et al., 2021).

Table 4: Cognitive Strategies

\begin{tabular}{|c|c|c|c|c|c|c|c|}
\hline No & Item & $\begin{array}{l}N, n \\
(\%)\end{array}$ & $\begin{array}{l}\text { NT, n } \\
(\%)\end{array}$ & $\begin{array}{l}\text { ST, n } \\
(\%)\end{array}$ & $\begin{array}{l}T, n \\
(\%)\end{array}$ & $\begin{array}{l}\text { AT, n } \\
(\%)\end{array}$ & Mear \\
\hline 10 & $\begin{array}{l}\text { I say or write new } \\
\text { English words several } \\
\text { times. }\end{array}$ & $\begin{array}{l}2 \\
(3.7)\end{array}$ & $\begin{array}{l}2 \\
(3.7)\end{array}$ & $\begin{array}{l}13 \\
(24.1)\end{array}$ & $\begin{array}{l}22 \\
(40.7)\end{array}$ & $\begin{array}{l}15 \\
(27.8)\end{array}$ & $\begin{array}{l}3.851 \\
9\end{array}$ \\
\hline 11 & $\begin{array}{l}\text { I try to talk like native } \\
\text { English speakers. }\end{array}$ & $\begin{array}{l}2 \\
(3.7)\end{array}$ & $\begin{array}{l}10 \\
(18.5)\end{array}$ & $\begin{array}{l}12 \\
(22.2)\end{array}$ & $\begin{array}{l}18 \\
(33.3)\end{array}$ & $\begin{array}{l}12 \\
(22.2) \\
\end{array}$ & $\begin{array}{l}3.518 \\
5\end{array}$ \\
\hline 12 & $\begin{array}{l}\text { I practice the sounds of } \\
\text { English. }\end{array}$ & 0 & 0 & $\begin{array}{l}5 \\
(9.3)\end{array}$ & $\begin{array}{l}29 \\
(53.7) \\
\end{array}$ & $\begin{array}{l}20 \\
(37.0) \\
\end{array}$ & $\begin{array}{l}4.277 \\
8\end{array}$ \\
\hline 13 & $\begin{array}{l}\text { I use the English words I } \\
\text { know in different ways. }\end{array}$ & $\begin{array}{l}1 \\
(1.9)\end{array}$ & 0 & $\begin{array}{l}8 \\
(14.8)\end{array}$ & $\begin{array}{l}29 \\
(53.7)\end{array}$ & $\begin{array}{l}16 \\
(29.6)\end{array}$ & $\begin{array}{l}4.092 \\
6\end{array}$ \\
\hline 14 & $\begin{array}{l}\text { I start conversations in } \\
\text { English. }\end{array}$ & $\begin{array}{l}1 \\
(1.9)\end{array}$ & $\begin{array}{l}1 \\
(1.9)\end{array}$ & $\begin{array}{l}14 \\
(25.9)\end{array}$ & $\begin{array}{l}22 \\
(40.7)\end{array}$ & $\begin{array}{l}16 \\
(29.6)\end{array}$ & $\begin{array}{l}3.944 \\
4\end{array}$ \\
\hline 15 & $\begin{array}{l}\text { I watch English } \\
\text { language TV shows } \\
\text { spoken in English or go } \\
\text { to movies spoken in } \\
\text { English. }\end{array}$ & $\begin{array}{l}1 \\
(1.9)\end{array}$ & 0 & $\begin{array}{l}2 \\
(3.7)\end{array}$ & $\begin{array}{l}11 \\
(20.4)\end{array}$ & $\begin{array}{l}40 \\
(74.1)\end{array}$ & $\begin{array}{l}4.648 \\
1\end{array}$ \\
\hline 16 & $\begin{array}{l}\text { I read for pleasure in } \\
\text { English. }\end{array}$ & $\begin{array}{l}1 \\
(1.9)\end{array}$ & $\begin{array}{l}1 \\
(1.9)\end{array}$ & $\begin{array}{l}10 \\
(18.5)\end{array}$ & $\begin{array}{l}8 \\
(14.8)\end{array}$ & $\begin{array}{l}34 \\
(63.0)\end{array}$ & $\begin{array}{l}4.351 \\
9\end{array}$ \\
\hline 17 & $\begin{array}{l}\text { I write notes, messages, } \\
\text { letters, or reports in } \\
\text { English. }\end{array}$ & 0 & $\begin{array}{l}2 \\
(3.7)\end{array}$ & $\begin{array}{l}6 \\
(11.1)\end{array}$ & $\begin{array}{l}14 \\
(25.9)\end{array}$ & $\begin{array}{l}32 \\
(59.3)\end{array}$ & $\begin{array}{l}4.407 \\
4\end{array}$ \\
\hline 18 & $\begin{array}{l}\text { I first skim an English } \\
\text { passage (read over the }\end{array}$ & $\begin{array}{l}3 \\
(5.6)\end{array}$ & $\begin{array}{l}2 \\
(3.7)\end{array}$ & $\begin{array}{l}3 \\
(5.6)\end{array}$ & $\begin{array}{l}27 \\
(50.0)\end{array}$ & $\begin{array}{l}19 \\
(35.2)\end{array}$ & $\begin{array}{l}4.055 \\
6\end{array}$ \\
\hline
\end{tabular}




\begin{tabular}{|c|c|c|c|c|c|c|c|}
\hline & $\begin{array}{l}\text { passage quickly) then } \\
\text { go back and read } \\
\text { carefully. }\end{array}$ & & & & & & \\
\hline 19 & $\begin{array}{l}\text { I look for words in my } \\
\text { own language that are } \\
\text { similar to new words in } \\
\text { English. }\end{array}$ & $\begin{array}{l}7 \\
(13.0)\end{array}$ & $\begin{array}{l}15 \\
(27.8)\end{array}$ & $\begin{array}{l}13 \\
(24.1)\end{array}$ & $\begin{array}{l}12 \\
(22.2)\end{array}$ & $\begin{array}{l}7 \\
(13.0)\end{array}$ & $\begin{array}{l}2.944 \\
4\end{array}$ \\
\hline 20 & $\begin{array}{l}\text { I try to find patterns in } \\
\text { English. }\end{array}$ & $\begin{array}{l}2 \\
(3.7) \\
\end{array}$ & $\begin{array}{l}7 \\
(13.0) \\
\end{array}$ & $\begin{array}{l}14 \\
(25.9) \\
\end{array}$ & $\begin{array}{l}20 \\
(37.0) \\
\end{array}$ & $\begin{array}{l}11 \\
(20.4) \\
\end{array}$ & $\begin{array}{l}3.574 \\
1 \\
\end{array}$ \\
\hline 21 & $\begin{array}{l}\text { I find the meaning of an } \\
\text { English word by } \\
\text { dividing it into parts } \\
\text { that I understand. }\end{array}$ & $\begin{array}{l}5 \\
(9.3)\end{array}$ & $\begin{array}{l}6 \\
(11.1)\end{array}$ & $\begin{array}{l}13 \\
(24.1)\end{array}$ & $\begin{array}{l}18 \\
(22.2)\end{array}$ & $\begin{array}{l}12 \\
(22.2)\end{array}$ & $\begin{array}{l}3.481 \\
5\end{array}$ \\
\hline 22 & $\begin{array}{l}\text { I try not to translate } \\
\text { English word for word. }\end{array}$ & $\begin{array}{l}3 \\
(5.6)\end{array}$ & $\begin{array}{l}1 \\
(1.9) \\
\end{array}$ & $\begin{array}{l}6 \\
(11.1)\end{array}$ & $\begin{array}{l}22 \\
(40.7)\end{array}$ & $\begin{array}{l}20 \\
(40.7)\end{array}$ & $\begin{array}{l}4.092 \\
6\end{array}$ \\
\hline 23 & $\begin{array}{l}\text { I make summaries of } \\
\text { information that I hear } \\
\text { or read in English. }\end{array}$ & 0 & $\begin{array}{l}1 \\
(1.9)\end{array}$ & $\begin{array}{l}11 \\
(20.4)\end{array}$ & $\begin{array}{l}21 \\
(38.9)\end{array}$ & $\begin{array}{l}21 \\
(38.9)\end{array}$ & $\begin{array}{l}4.148 \\
1\end{array}$ \\
\hline
\end{tabular}

For the cognitive strategies, Table 4 displays that the "I watch English language TV shows spoken in English or go to movies spoken in English" (item 16) strategy was highly utilised as its mean score is 4.6481 as it is similar with the finding on the research done by Yunus et al. (2013). In contrary, Rahman (2020) found that the strategy "I watch English language TV shows spoken in English or go to movies spoken in English" (item 16) as the least frequent strategies used by the EFL learners of a university in Saudi Arab. Meanwhile, "I look for words in my own language that are similar to new words in English" (item 19) strategy reported the lowest mean (2.944) which means it was the lowest used. Both findings are in line with the research done by Nazri et al. (2016). Oxford (2003) mentioned that utilizing cognitive strategies allow language learners to manipulate the language material in direct ways. By looking at the contradicting result of Rahman (2020), it can be concluded that context may play a role for the usage of strategies among the language learners. 
Table 5: Compensation strategies

\begin{tabular}{|c|c|c|c|c|c|c|c|}
\hline No & Item & $\begin{array}{l}\mathrm{N}, \mathrm{n} \\
(\%) \\
\end{array}$ & $\begin{array}{l}\text { NT, n } \\
(\%)\end{array}$ & $\begin{array}{l}\text { ST, n } \\
(\%) \\
\end{array}$ & $\begin{array}{l}T, n \\
(\%) \\
\end{array}$ & $\begin{array}{l}\text { AT, n } \\
(\%) \\
\end{array}$ & Mean \\
\hline 24 & $\begin{array}{lr}\text { To } & \text { understand } \\
\text { unfamiliar } & \text { English } \\
\text { words, I make guesses. }\end{array}$ & 0 & 0 & $\begin{array}{l}2 \\
(3.7)\end{array}$ & $\begin{array}{l}24 \\
(44.4)\end{array}$ & $\begin{array}{l}28 \\
(51.9)\end{array}$ & $\begin{array}{l}4.481 \\
5\end{array}$ \\
\hline 25 & $\begin{array}{l}\text { When I cannot think of } \\
\text { a word during a } \\
\text { conversation in the } \\
\text { English, I use gestures. }\end{array}$ & $\begin{array}{l}1 \\
(1.9)\end{array}$ & $\begin{array}{l}3 \\
(5.6)\end{array}$ & $\begin{array}{l}9 \\
(16.7)\end{array}$ & $\begin{array}{l}19 \\
(35.2)\end{array}$ & $\begin{array}{l}22 \\
(40.7)\end{array}$ & $\begin{array}{l}4.074 \\
1\end{array}$ \\
\hline 26 & $\begin{array}{l}\text { I make up new words if } \\
\text { I do not know the right } \\
\text { ones in English. }\end{array}$ & $\begin{array}{l}9 \\
(16.7)\end{array}$ & $\begin{array}{l}16 \\
(29.6)\end{array}$ & $\begin{array}{l}10 \\
(18.5)\end{array}$ & $\begin{array}{l}13 \\
(24.1)\end{array}$ & $\begin{array}{l}6 \\
(11.1)\end{array}$ & $\begin{array}{l}2.833 \\
3\end{array}$ \\
\hline 27 & $\begin{array}{l}\text { I read English without } \\
\text { looking up every new } \\
\text { word. }\end{array}$ & $\begin{array}{l}2 \\
(3.7)\end{array}$ & $\begin{array}{l}4 \\
(7.4)\end{array}$ & $\begin{array}{l}12 \\
(22.2)\end{array}$ & $\begin{array}{l}11 \\
(20.4)\end{array}$ & $\begin{array}{l}25 \\
(46.3)\end{array}$ & $\begin{array}{l}3.981 \\
5\end{array}$ \\
\hline 28 & $\begin{array}{l}\text { I try to guess what the } \\
\text { other person will say } \\
\text { next in English. }\end{array}$ & $\begin{array}{l}4 \\
(7.4)\end{array}$ & $\begin{array}{l}1 \\
(1.9)\end{array}$ & $\begin{array}{l}14 \\
(25.9)\end{array}$ & $\begin{array}{l}20 \\
(37.0)\end{array}$ & $\begin{array}{l}15 \\
(27.8)\end{array}$ & $\begin{array}{l}3.759 \\
3\end{array}$ \\
\hline 29 & $\begin{array}{l}\text { If I cannot think of an } \\
\text { English word, I use a } \\
\text { word or phrase that } \\
\text { means the same thing. }\end{array}$ & 0 & 0 & $\begin{array}{l}1 \\
(1.9)\end{array}$ & $\begin{array}{l}18 \\
(33.3)\end{array}$ & $\begin{array}{l}35 \\
(64.8)\end{array}$ & $\begin{array}{l}4.629 \\
6\end{array}$ \\
\hline
\end{tabular}

Based on the data revealed in Table 5 of the compensation strategies, "if I cannot think of an English word, I use a word or phrase that means the same thing." (item 29) was the most preferred strategy with the mean 4.6296 which similar with finding by Yunus et al. (2013) and Rahman (2020). Whereas "I make up new words if I do not know the right ones in English" (item 26) was the least used strategy, where the mean score only carried 2.8333. Both results are similar to the finding by Nazri et al. (2016) and Ang et al. (2017). Oxford (1990) stated that compensation strategies are useful to overcome any limitation of knowledge in the four skills which are reading, writing, speaking, listening. The finding indicates that the respondents tend to dig for words when using English language and not easily find a way to use their first language instead. 
Table 6: Metacognitive Strategies

\begin{tabular}{|c|c|c|c|c|c|c|c|}
\hline No & Item & $\begin{array}{l}N, n \\
(\%)\end{array}$ & $\begin{array}{l}\text { NT, n } \\
(\%)\end{array}$ & $\begin{array}{l}\text { ST, n } \\
(\%)\end{array}$ & $\begin{array}{l}\mathrm{T}, \mathrm{n} \\
(\%)\end{array}$ & $\begin{array}{l}\text { AT, n } \\
(\%)\end{array}$ & Mean \\
\hline 30 & $\begin{array}{l}\text { I try to find as many } \\
\text { ways as I can to use my } \\
\text { English. }\end{array}$ & 0 & 0 & $\begin{array}{l}7 \\
(13.0)\end{array}$ & $\begin{array}{l}18 \\
(33.3)\end{array}$ & $\begin{array}{l}29 \\
(53.7)\end{array}$ & $\begin{array}{l}4.407 \\
4\end{array}$ \\
\hline 31 & $\begin{array}{l}\text { I notice my English } \\
\text { mistakes and use that } \\
\text { information to help me } \\
\text { do better. }\end{array}$ & 0 & 0 & $\begin{array}{l}3 \\
(5.6)\end{array}$ & $\begin{array}{l}21 \\
(38.9)\end{array}$ & $\begin{array}{l}20 \\
(55.6)\end{array}$ & $\begin{array}{l}4.500 \\
0\end{array}$ \\
\hline 32 & $\begin{array}{l}\text { I pay attention when } \\
\text { someone is speaking } \\
\text { English. }\end{array}$ & 0 & 0 & $\begin{array}{l}2 \\
(3.7)\end{array}$ & $\begin{array}{l}20 \\
(37.0)\end{array}$ & $\begin{array}{l}32 \\
(59.3)\end{array}$ & $\begin{array}{l}4.555 \\
6\end{array}$ \\
\hline 33 & $\begin{array}{l}\text { I try to find out how to } \\
\text { be a better learner of } \\
\text { English. }\end{array}$ & 0 & 0 & $\begin{array}{l}2 \\
(3.7)\end{array}$ & $\begin{array}{l}20 \\
(37.0)\end{array}$ & $\begin{array}{l}32 \\
(59.3)\end{array}$ & $\begin{array}{l}4.555 \\
6\end{array}$ \\
\hline 34 & $\begin{array}{l}\text { I plan my schedule so I } \\
\text { will have enough time } \\
\text { to study English. }\end{array}$ & $\begin{array}{l}3 \\
(5.6)\end{array}$ & $\begin{array}{l}10 \\
(18.5)\end{array}$ & $\begin{array}{l}19 \\
(35.2)\end{array}$ & $\begin{array}{l}10 \\
(18.5)\end{array}$ & $\begin{array}{l}12 \\
(22.2)\end{array}$ & $\begin{array}{l}3.333 \\
3\end{array}$ \\
\hline 35 & $\begin{array}{l}\text { I look for people I can } \\
\text { talk to in English. }\end{array}$ & 0 & $\begin{array}{l}1 \\
(1.9) \\
\end{array}$ & $\begin{array}{l}14 \\
(25.9) \\
\end{array}$ & $\begin{array}{l}16 \\
(29.6) \\
\end{array}$ & $\begin{array}{l}23 \\
(42.6) \\
\end{array}$ & $\begin{array}{l}4.129 \\
6 \\
\end{array}$ \\
\hline 36 & $\begin{array}{l}\text { I look for opportunities } \\
\text { to read as much as } \\
\text { possible in English. }\end{array}$ & 0 & 0 & $\begin{array}{l}6 \\
(11.1)\end{array}$ & $\begin{array}{l}18 \\
(33.3)\end{array}$ & $\begin{array}{l}30 \\
(55.6)\end{array}$ & $\begin{array}{l}4.444 \\
4\end{array}$ \\
\hline 37 & $\begin{array}{l}\text { I have clear goals for } \\
\text { improving my English } \\
\text { skills. }\end{array}$ & 0 & $\begin{array}{l}2 \\
(3.7)\end{array}$ & $\begin{array}{l}13 \\
(24.1)\end{array}$ & $\begin{array}{l}17 \\
(31.5)\end{array}$ & $\begin{array}{l}22 \\
(40.7)\end{array}$ & $\begin{array}{l}4.092 \\
6\end{array}$ \\
\hline 38 & $\begin{array}{l}\text { I think about my } \\
\text { progress in learning } \\
\text { English. }\end{array}$ & $\begin{array}{l}1 \\
(1.9)\end{array}$ & $\begin{array}{l}5 \\
(9.3)\end{array}$ & $\begin{array}{l}8 \\
(14.8)\end{array}$ & $\begin{array}{l}19 \\
(35.2)\end{array}$ & $\begin{array}{l}21 \\
(38.9)\end{array}$ & $\begin{array}{l}4.000 \\
0\end{array}$ \\
\hline
\end{tabular}

Table 6 revealed the mean score of metacognitive strategies ranging from 4.5556 to 3.3333 where the mean 4.5556 belongs to the most frequently used "I pay attention when someone is speaking English" (item 32) and "I try to find out how to be a better learner of English" (item 33) strategies, and the mean of 3.3333 to "I plan my schedule so I will have enough time to study English" (item 34) the least used metacognitive strategy. Interestingly, both items 32 and 34 have similar finding with Yunus et al. (2013), Nazri et al. (2016) and Rahman (2020). Meanwhile, Ang et al. (2017) too found that item 33 was the most used among the metacognitive strategies.

Oxford (2003) stated that metacognitive strategies are usually utilised for managing the overall learning process and used as a strong predicted of second language proficiency. These strategies can positively influence learners by supporting them to deeply think about the content of the language (Ang et al., 2017). Paying attention and constantly trying to improve oneself are among the criteria of effective educators and good language learners. Good language learners learn actively by solving their own problem when learning (Fitriani, 2020). Therefore, via reflecting on the gaps they learn better 
Table 7: Affective Strategies

\begin{tabular}{|c|c|c|c|c|c|c|c|}
\hline No & Item & $\begin{array}{l}N, n \\
(\%)\end{array}$ & $\begin{array}{l}\text { NT, n } \\
(\%)\end{array}$ & $\begin{array}{l}\text { ST, n } \\
\text { (\%) }\end{array}$ & $\begin{array}{l}T, n \\
(\%)\end{array}$ & $\begin{array}{l}\text { AT, n } \\
(\%)\end{array}$ & Mean \\
\hline 39 & $\begin{array}{l}\text { I try to relax whenever } \\
\text { I feel afraid of using } \\
\text { English. }\end{array}$ & $\begin{array}{l}2 \\
(3.7)\end{array}$ & $\begin{array}{l}4 \\
(7.4)\end{array}$ & $\begin{array}{l}10 \\
(18.5)\end{array}$ & $\begin{array}{l}16 \\
(29.6)\end{array}$ & $\begin{array}{l}22 \\
(40.7)\end{array}$ & $\begin{array}{l}3.963 \\
0\end{array}$ \\
\hline 40 & $\begin{array}{l}\text { I encourage myself to } \\
\text { speak English even } \\
\text { when I am afraid of } \\
\text { making a mistake. }\end{array}$ & $\begin{array}{l}2 \\
(3.7)\end{array}$ & $\begin{array}{l}1 \\
(1.9)\end{array}$ & $\begin{array}{l}5 \\
(9.3)\end{array}$ & $\begin{array}{l}18 \\
(33.3)\end{array}$ & $\begin{array}{l}28 \\
(51.9)\end{array}$ & $\begin{array}{l}4.277 \\
8\end{array}$ \\
\hline 41 & $\begin{array}{l}\text { I give myself a reward } \\
\text { or treat when I do well } \\
\text { in English. }\end{array}$ & $\begin{array}{l}11 \\
(20.4)\end{array}$ & $\begin{array}{l}6 \\
(11.1)\end{array}$ & $\begin{array}{l}16 \\
(29.6)\end{array}$ & $\begin{array}{l}15 \\
(27.8)\end{array}$ & $\begin{array}{l}6 \\
(11.1)\end{array}$ & $\begin{array}{l}2.981 \\
5\end{array}$ \\
\hline 42 & $\begin{array}{l}\text { I notice if I am tense or } \\
\text { nervous when I am } \\
\text { studying or using } \\
\text { English. }\end{array}$ & $\begin{array}{l}6 \\
(11.1)\end{array}$ & $\begin{array}{l}16 \\
(29.6)\end{array}$ & $\begin{array}{l}12 \\
(22.2)\end{array}$ & $\begin{array}{l}8 \\
(14.8)\end{array}$ & $\begin{array}{l}12 \\
(22.2)\end{array}$ & $\begin{array}{l}3.074 \\
1\end{array}$ \\
\hline 43 & $\begin{array}{l}\text { I write down my } \\
\text { feelings in a language } \\
\text { learning dairy. }\end{array}$ & $\begin{array}{l}17 \\
(31.5)\end{array}$ & $\begin{array}{l}14 \\
(25.9)\end{array}$ & $\begin{array}{l}10 \\
(18.5)\end{array}$ & $\begin{array}{l}5 \\
(9.3)\end{array}$ & $\begin{array}{l}8 \\
(14.8)\end{array}$ & $\begin{array}{l}2.500 \\
0\end{array}$ \\
\hline 44 & $\begin{array}{l}\text { I talk to someone else } \\
\text { about how I feel when } \\
\text { I am learning English. }\end{array}$ & $\begin{array}{l}12 \\
(22.2)\end{array}$ & $\begin{array}{l}10 \\
(18.5)\end{array}$ & $\begin{array}{l}10 \\
(18.5)\end{array}$ & $\begin{array}{l}11 \\
(20.4)\end{array}$ & $\begin{array}{l}11 \\
(20.4)\end{array}$ & $\begin{array}{l}2.981 \\
5\end{array}$ \\
\hline
\end{tabular}

The result of affective strategies (Table 7) exhibits the "I encourage myself to speak English even" (item 40) with the mean score of 4.2778, the highest frequency which is parallel with the research by Yunus et al. (2013) and Nazri et al (2016). On the other hand, the lowest mean score (2.5000) was recorded for "I write down my feelings in a language learning diary" (item 43) strategy, the rarest used strategy. The result is similar to the finding by Yunus et al. (2013), Ang et al. (2017) and Rahman (2020). Affective strategies are significantly associated with second language proficiency, but students no longer use much of these strategies as they progress to higher proficiency (Oxford, 2003). This study supports Oxford's claim as overall affective strategies were the least used among the respondents. According to Ang et al. (2017), learners required both intrinsic and extrinsic motivation to promote their language competency and proficiency. Thus, encouraging own self is a crucial factor to be a successful language learner (Adan and Hashim, 2021). 
Table 8: Social Strategies

\begin{tabular}{|c|c|c|c|c|c|c|c|}
\hline No & Item & $\begin{array}{l}N, n \\
(\%)\end{array}$ & $\begin{array}{l}\text { NT, n } \\
(\%)\end{array}$ & $\begin{array}{l}\text { ST, } n \\
(\%)\end{array}$ & $\begin{array}{l}\mathrm{T}, \mathrm{n} \\
(\%)\end{array}$ & $\begin{array}{l}\text { AT, n } \\
(\%)\end{array}$ & Mean \\
\hline 45 & $\begin{array}{l}\text { If I do not understand } \\
\text { something in English, I } \\
\text { ask the other person } \\
\text { to slow down or say it } \\
\text { again. }\end{array}$ & $\begin{array}{l}2 \\
(3.7)\end{array}$ & $\begin{array}{l}2 \\
(3.7)\end{array}$ & $\begin{array}{l}9 \\
(16.7)\end{array}$ & $\begin{array}{l}23 \\
(42.6)\end{array}$ & $\begin{array}{l}18 \\
(33.3)\end{array}$ & $\begin{array}{l}3.981 \\
5\end{array}$ \\
\hline 46 & $\begin{array}{l}\text { I ask English speakers } \\
\text { to correct me when I } \\
\text { talk. }\end{array}$ & $\begin{array}{l}4 \\
(7.4)\end{array}$ & $\begin{array}{l}14 \\
(25.9)\end{array}$ & $\begin{array}{l}12 \\
(22.2)\end{array}$ & $\begin{array}{l}14 \\
(25.9)\end{array}$ & $\begin{array}{l}10 \\
(18.5)\end{array}$ & $\begin{array}{l}3.222 \\
2\end{array}$ \\
\hline 47 & $\begin{array}{l}\text { I practice English with } \\
\text { other students. }\end{array}$ & 0 & $\begin{array}{l}2 \\
(3.7) \\
\end{array}$ & $\begin{array}{l}5 \\
(9.3) \\
\end{array}$ & $\begin{array}{l}21 \\
(38.9) \\
\end{array}$ & $\begin{array}{l}26 \\
(48.1) \\
\end{array}$ & $\begin{array}{l}4.314 \\
8 \\
\end{array}$ \\
\hline 48 & $\begin{array}{l}\text { I ask for help from } \\
\text { English speakers. }\end{array}$ & $\begin{array}{l}2 \\
(3.7)\end{array}$ & $\begin{array}{l}3 \\
(5.6)\end{array}$ & $\begin{array}{l}20 \\
(37.0)\end{array}$ & $\begin{array}{l}15 \\
(27.8)\end{array}$ & $\begin{array}{l}14 \\
(25.9)\end{array}$ & $\begin{array}{l}3.666 \\
7\end{array}$ \\
\hline 49 & $\begin{array}{l}\text { ask questions in } \\
\text { English. }\end{array}$ & 0 & 0 & $\begin{array}{l}7 \\
(13.0)\end{array}$ & $\begin{array}{l}19 \\
(35.2)\end{array}$ & $\begin{array}{l}28 \\
(51.9)\end{array}$ & $\begin{array}{l}4.388 \\
9\end{array}$ \\
\hline 50 & $\begin{array}{l}\text { I try to learn about the } \\
\text { culture of English } \\
\text { speakers. }\end{array}$ & $\begin{array}{l}1 \\
(1.9)\end{array}$ & $\begin{array}{l}7 \\
(13.0)\end{array}$ & $\begin{array}{l}15 \\
(27.8)\end{array}$ & $\begin{array}{l}13 \\
(24.1)\end{array}$ & $\begin{array}{l}18 \\
(33.3)\end{array}$ & $\begin{array}{l}3.740 \\
7\end{array}$ \\
\hline
\end{tabular}

As indicated in Table 8, the "I ask English speakers to correct me when I talk" (item 46) was the least frequently utilised social strategy with the mean of 3.2222. The finding of Nazri et al. (2016) is alike, as they also found that item 46 was the least used strategies in their research. Meanwhile "I ask questions in English" (item 49) strategy as the most utilised social strategy for English language learning with mean score 4.3889 which is similar to the finding by Ang et al. (2017) and Rahman (2020). Asking for clarification and repetition as strategies allow opportunities for the learners to experience meaningful learning (Ang et al., 2017). Successful language learners find opportunity to learn the target language via any available resources (Nazri et al., 2016). In case of social strategies, English speakers play the role of being the resource from which learners can learn.

\section{Implications and Conclusion}

This quantitative study attempts to reveal the language learning strategies preferred by ESL teachers and lecturers' (successful language learners) via SILL questionnaire by Oxford (1990). The findings of the study imply that the participants have reported high frequent use of five of the six categories of language learning strategies suggested by Oxford (1990) namely metacognitive, compensation, cognitive, social and memory and moderate use of affective strategies. This shows that the ESL educators are more aware of the strategies they use to learn English language besides using most of the strategies regularly. It is a positive sign where the ESL educators are more conscious of their language learning strategies used which may help them to expose their students to varieties of strategies when teaching. Educators should train their students to use strategies when learning language. So, students will be able to knowingly find specific strategies that suit them to learn language at their best. Second language teachers may benefit from assessment of strategies utilised by their learners to enhance understanding of the strategies (Oxford, 2003). Awareness of language learning strategies can substantially boost teaching and learning process (Nazri et. al, 2016). 
Via this study, syllabus designers and material developers may learn about the most used strategies for each category of strategies by successful language learners and use the information to enhance English language syllabus and materials with regards to the four skills. Materials which may support learners to learn the syllabus effectively via applying language learning strategies can lead the learners to fasten their language learning development. Besides, teachers can benefit from this study as they will be able to make best use of the strategies in their instructions. As it is crucial for teachers to train students to use language learning strategies, it is also imperative for them to make sure their instructions lead to best learning experience for their students. Therefore, by being aware of the language learning strategies used by them to be successful language learners, they will be very sure and confident when training students to utilise the strategies so that their students too will excel in their language learning journey. Significantly, by referring to this study, students or other language learners may find out the most and least strategies preferred by ESL teachers and lecturers who are their role model when it comes to learning.

\section{References}

Adan, D. A., \& Hashim, H. (2021). Language Learning Strategies Used by Art School ESL Learners. Creative Education, 12, 653-665. https://doi.org/10.4236/ce.2021.123045

Ang, S., Embi, M. A., \& Yunus, M. M. (2017). Strategies of Successful English Language Learners among Private School Students. Jurnal Pendidikan Humaniora, 5(2), 47-57. https://doi.org/10.17977/um030v5i22017p047

Basri, H., \& Hashim, H. (2019). Language Learning Strategies Used By Successful English as a Second Language (ESL) Learners among Primary School Students. 5(2), 9-12.

Cohen, A. D. (1998). Strategies in learning and using a second language. London: Longman

Creswell, J. W. (2012). Educational research planning, conducting and evaluating quantitative and qualitative research. New York City: Pearson.

Education First, E. F. (2019). EF English Proficiency Index A Ranking of 100 Countries and Regions by English Skills. https://www.ef.com/wwen/epi/

Education First, E. F. (2020). EF English Proficiency Index A Ranking of 100 Countries and Regions by English Skills. https://www.ef.com/wwen/epi/

Ernomo, Z. (2018). Language Learning Strategies ( LLS ) Instruction to Help Students Become Better Language Learners. 2(2), 79-83.

Fitriani, V. F. (2020). Portraying Efl Students' Learning S Tyles in Utilizing Mobile - Assisted Language Learning: How To Be a Good Language Learner? Journal of Teaching \& Learning English in Multicultural Contexts (TLEMC), 4(1), 34-45.

Hashim, H. U., Yunus, M. M., \& Hashim, H. (2018). Language Learning Strategies Used by Adult Learners of Teaching English as a Second Language (TESL). TESOL International Journal, 13(4), 39-48.

Kiu, C. S. L., \& Yamat, H. (2020). Reading Strategy Use among Good and Poor Primary English as a Second Language Learners. International Journal of Academic Research in Business and Social Sciences, 10(1). https://doi.org/10.6007/ijarbss/v10-i1/6853

Koç, H. K. (2017). International Journal of Languages ' Education and Teaching. International Journal of Languages' Education and Teaching, 5(1), 359-376. http://files.eric.ed.gov/fulltext/ED574953.pdf

Kussin, H. J., Omar, A., \& Kepol, N. (2018). Language Learning Strategies (LLS): Teachers' Notions and Practice. Dinamika IImu, 18(1), 109-122.

https://doi.org/10.21093/di.v18i1.1086 
Lim, T. M., Sze, D. W. L., Raki, D., Lim, L. M., Sani, S., \& Hashim, H. (2021). Year 6 Pupils' Language Learning Strategies in Learning English Grammar. International Journal of Academic Research in Business and Social Sciences, 11(4), 1196-1209. https://doi.org/10.6007/IJARBSS/v11-i4/9690

MOE. (2013). Pelan Pembangunan Pendidikan Malaysia 2013-2025. Putrajaya: Kementerian Pendidikan Malaysia.

MOE. (2015). English Language Education Reform in Malaysia: The Roadmap 2015-2025. Putrajaya: Kementerian Pendidikan Malaysia.

Musa, N. C., Lie, K. Y., \& Azman, H. (2012). Exploring English language learning and teaching in Malaysia. GEMA Online Journal of Language Studies, 12(1), 35-51.

Nadif, B., \& Benattabou, D. (2021). International Journal of Linguistics, Literature and Translation (IJLLT) The Impact of Students' Proficiency in English on Science Courses in a Foundation Year Program. International Journal of Linguistics, Literature and Translation (IJLLT), 4(3), 61-73. https://doi.org/10.32996/ijllt

Nazri, N. M., Yunus, M. M., Nazri, N. D., \& Mohamad. (2016). Through the Lens of Good Language Learners: What Are Their Strategies? Advances in Language and Literary Studies, 7(1), 195-202. https://doi.org/10.7575/aiac.alls.v.7n.1p.195

O'Malley, J. M., \& Chamot, A. U. (1990). Learning strategies in second language acquisition. Cambridge: Cambridge University Press.

O’Malley, J. M., Chamot, A. U., Stewner-Manzanares, G., Russo, R. P., Küpper, L., \& Kupper, L. (1985). Learning Strategy Applications with Students of English as a Second Language. TESOL Quarterly, 19(3), 557. https://doi.org/10.2307/3586278

Oxford, R., \& Crookall, D. (1989). Research on Language Learning Methods, Findings, Strategies : and Instructional Issues. The Modern Language Journal, 73(4), 404-419.

Oxford, R. (1990). Language Learning Strategies: What Every Teacher Should Know. Boston: Heinle and Heinle.

Oxford, R. L. (Ed.). (2003). Language learning styles and strategies. Mouton de Gruyter.

Rahman, M. M. UR. (2020). EFL Learners' Language Learning Strategies: A Case Study at Qassim University. Advances in Language and Literary Studies, 11(5), 6. https://doi.org/10.7575/aiac.alls.v.11n.5p.6

Rubaai, N., \& Hashim, H. (2019). Identifying English language learning strategies used by polytechnic students. Religación, 4, 98-103.

Rubin, J. (1975). What a Good Language Learners Can Teach Us. TESOL Quarterly, 9(1), 41-51. http://www.jstor.org/stable/3586011

Sarafianou, A., \& Gavriilidou, Z. (2015). The effect of strategy-based instruction on strategy use by upper-secondary Greek students of EFL. Electronic Journal of Foreign Language Teaching, 12(1), 21-34.

Shi, H. (2017). Learning strategies and classification in education. Institute for Learning Styles Journal, 1(1), 24-36.

Wenden, A., \& Rubin, J. (1987). Learner strategies in language learning. Englewood Cliffs, NJ:Prentice Hall. Zakaria, N. Y. K., Zakaria, S. N., \& Azmi, N. E. (2018). Language Learning Strategies Used by Secondary Schools Students in Enhancing Speaking Skills. Creative Education, 09(14), 2357-2366. https://doi.org/10.4236/ce.2018.914176

Zare, P. (2012). Language learning strategies among EFL/ESL learners a review of literature. International Journal of Humanities and Social Science, 2(5), 162-169. 